\title{
Penggunaan Media Beruang Antik Berbasis STEAM pada Materi Bangun Ruang Siswa Sekolah Dasar
}

\author{
Ani Kholifatul Khoir \\ SD Negeri Banggle 02 Kecamatan Kanigoro, Kabupaten Blitar \\ Email: khoirsmartblitar@gmail.com
}

Riwayat artikel: submit: 31 Agustus 2021; revisi: 25 September 2021, diterima: 30 September 2021

\begin{abstract}
ABSTRAK
Kondisi pada wabah Pandemi Covid -19 yang sedang mewabah di Indonesia ini sangat berpengaruh di segala 176eknik, salah satunya di bidang pendidikan. Dunia pendidikan merasakan dampak yang sangat luar biasa terutama guru dalam proses belajar, agar pembelajaran tetap menyenangkan meskipun belajar di rumah. Sehingga guru diminta dan dipaksa untuk menbuat perangkat pembelajaran sebagai solusi dan inovasi melalui pemanfaatan berbagai perangkat pembelajaran serta aplikasi daring (online). Media pembelajaran Beruang Antik berbasis STEAM diantaranya disiplin sains, teknologi, Teknik, seni, dan matematika ini peserta didik diajak untuk dapat berpikir secara kritis dengan metode belajar memecahkan masalah serta dapat menggunakan kecanggihan alat teknologi dan strategi belajar yang aktif dan kreatif. Media Beruang Antik dapat membantu peserta didik meningkatkan keterampilan perpikir kreatif dan keterampilan berkomunikasi. Dalam pelaksanaan pembelajaran, media Beruang Antik memberdayakan keterlibatan orang tua, untuk mengarahkan peserta didik menyelesaikan masalah, mendorong peserta didik berekplorasi, menemukan cara-cara baru. Keterlibatan Orang tua inilah yang akan membuat pembelajaran secara daring menggunakan Media Berung Antik ini dapat berjalan maksimal.
\end{abstract}

Kata kunci : Pandemi Covid-19, Media Beruang Antik, STEAM

\section{ABSTRACT}

The conditions in the Covid-19 pandemic that are endemic in Indonesia are very influential in all fields, one of which is in the field of education. The world of education feels a tremendous impact, especially teachers in the learning process, so that learning remains fun even though studying at home. So that teachers are asked and forced to make learning tools as solutions and innovations through the use of various learning tools and online applications (online). The STEAM-based Antique Bear learning media includes the disciplines of science, technology, engineering, art, and mathematics. The students are invited to think critically with problem-solving learning methods and can use advanced technology tools and active and creative learning strategies. Antique Bear Media can help students improve their creative thinking skills and communication skills. In the implementation of learning, the Antique Bear media empowers the involvement of parents, to direct students to solve problems, encourage students to explore, find new ways. Parental involvement is what will make online learning using this Antique Berung Media run optimally.

Keywords: Covid-19 Pandemic, Antique Bear Media, STEAM

Copyright (C) 2021 The Author(s)

This is an open access article under the CC BY-SA license. 
Khoir, A.K. (2021). Penggunaan Media Beruang Antik Berbasis STEAM pada Materi Bangun Ruang Siswa Sekolah Dasar. Edudikara: Jurnal Pendidikan dan Pembelajaran, 6(3), 176-186.

\section{PENDAHULUAN}

Wabah COVID-19 yang sedang mewabah ini sangat mempengauhi pada semua bidang, tak terkecuali pada bidang pendidikan. Dunia pendidikan merasakan dampak yang sangat luar biasa terutama sebagai pendidik. Seperti yang telah disampaikan oleh Siahaan (2020) bahwasannya pada bidang Pendidikan di Indonesia menjadi salah satu bidang diantara banyak bidang yang terdampak akibat adanya pandemi covid-19. Sama halnya yang disampaikan oleh Sudarmoyo (2020) bahwasannya dampak dari virus Corona ini membawa perubahan yang sangat besar dari berbagai sektor dan pereekonomian serta sosial dan pendidikan. Demi mengurangi penyebaran Covid-19 Pemerintah melalui Kemendikbud (2020) diterapkan kebijakan dalam kegiatan pembelajaran secara daring (dalam jaringan). Anugrahana (2020) menyampaikan bahwasannya pada saat kondisi pandemi ini menuntut pendidik (Guru) untuk berinovasi mengubah pola pembelajaran tatap muka menjadi pola pembelajaran tanpa tatap muka (daring) atau belajar dari rumah (BDR). Hal ini juga di dukung oleh penelitian dari Mahaly (2021) bahwasannya pelaksanaan pembelajaran daring program studi Bimbingan dan Konseling dalam kategori cukup dengan jumlah rata-rata $52.5 \%$ yang artinya pembelajaran daring menjadi salah satu pilihan untuk upaya pencegahan penyebaran virus. Sehingga untuk menanggulangi peyebaran COVID19, dan hal yang di kawatirkan adalah siswa dapat berperan sebagai pembawa dan penyebar tanpa gejala. Hampir seluruh negara didunia menghentikan pembelajaran di sekolah dan diganti melalui pembelajaran dari rumah atau disebut juga dengan BDR. Ini juga sesuai dengan Surat Edaran Nomor 4 Tahun 2020 tentang Pelaksanaan Kebijakan Pendidikan dalam Masa Darurat Penyebaran Corona Virus Disease (Covid-19) yaitu daerah zona kuning, orange dan merah dilarang melakukan pembelajaran tatap muka dan tetap melanjutkan Belajar dari Rumah (BDR). Dengan BDR sekolah, siswa, orang tua, dan tentu saja guru harus melakukan perubahan pembelajaran menjadi pembelajaran digital atau online, yang lebih dikenal dengan istilah $e$ learning atau pembelajaran dalam jaringan (daring).

Perubahan pembelajaran tatap muka menjadi Belajar dari Rumah (BDR) memunculkan berbagai permasalahan dalam iklim pendidikan. Dalam pembelajaran secara mandiri dapat diartikan sebagai proses bahwasannya siswa dilibatkan secara langsung dalam mengidentifikasi sesuatu perlu untuk dipelajari menjadi pemegang kendali pada proses pembelajaran, (Kirkman dalam Ismail et al., 2020). Namun Kementerian Pendidikan dan Kebudayaan Republik Indonesia dengan tegas memberlakukan kebijakan pembelajaran daring. Berdasarkan SE Sesjen Kemdikbud No.15 Tahun2020 bahwa Pelaksanaan Belajar Dari Rumah (BDR) selama darurat COVID-19 bertujuan untuk: 1.) Memastikan pemenuhan hakpeserta didik untuk mendapatkan layanan pendidikan selama darurat COVID-19; 2). Melindungi warga satuan pendidikan daridampak buruk COVID-19;3). Mencegah penyebaran dan penularan COVID-19 disatuan pendidikan; dan 4). Memastikan pemenuhan dukungan psikososial bagi pendidik, peserta didik dan orangtua atau wali. Guru harus siap dengan berbagai kondisi pembelajaran dan kondisi peserta didik, termasuk dengan berbagai dinamika pendidikan serta masalah yang terjadi di dalamnya. Guru harus memastikan supaya anak tetap melaksanakan proses belajar yang menyenangkan meskipun belajar dari rumah. Guru dituntut untuk kreatif membuat suatu perangkat pembelajaran sebagai pemecah masalah dan juga inovatif dengan memanfaatkan berbagai media pembelajaran serta aplikasi daring yang ada.

Berdasarkan wawancara dan survei pada peserta didik, pada pelajaran matematika yaitu salah satu diantara banyak mata pelajaran yang menjadi momok bagi sebagian peserta didik. Hal ini menjadi tantangan bagi guru untuk mendesain dan mengembangkan berbagai metode serta strategi pembelajaran matematika yang menyenangkan bagi peserta didik apalagi di saat wabah Pandemi Covid-19 ini. Gheytasi, Azizifar \& Gowhary dalam Khusniyah \& Hakim (2019) berpedapat bahwasannya beberapa penelitian terdahulu menunjukkan dengan adanya teknologi dapat memberikan pengaruh positif terhadap pembelajaran salah satunya adalah perkembangan jaringan internet yang merambah kedalam dunia pendidikan saat ini. Moore et 
Khoir, A.K. (2021). Penggunaan Media Beruang Antik Berbasis STEAM pada Materi Bangun Ruang Siswa Sekolah Dasar. Edudikara: Jurnal Pendidikan dan Pembelajaran, 6(3), 176-186.

al (dalam Firman \& Rahayu, 2020) membicarakan mengenai belajar mengajar secara online bahwasannya suatu kegiatan yang membutuhkan jaringan internet dan kemampuan untuk memunculkan berbagai jenis interaksi dan model pembelajaran. Guru dituntut untuk dapat memanfaatkan dan membuat media pembelajaran yang menarik bagi siswa terutama saat Belajar di rumah dimasa Pandemi Covid-19 ini. Primasari et al. (2014) juga menyatakan bahwa media dalam pembelajaranpada saat daring berfungsi untuk menghadirkan suatu objek atau kegiatan yang tidak dapat dilihat siswa secara langsung atau objek yang terlalu mikro untuk dapat dilihat langsung, misalnya memperbesar benda yang kecil, menyajikan peristiwa yang letaknya jauh, kompleks, rumit, yang langsung dengan sangat cepat atau lambat menjadi sistematik dan sederhana. Dari beberapa pernyataan pendapat diatas dapat disimpulkan bahwa dimasa pandemi Covid 19 ini Guru harus dapat memanfaatkan dan atau membuat media pembelajaran yang menarik bagi siswa sebagai wadah dan penyalur pesan dari guru kepada siswa yang berupa pesan atau informasi pendidikan sehingga siswa dapat berinteraksi aktif dalam pembelajaran. Maka dari itu Media Beruang Antik ini merupakan salah satu media pembelajaran dan sebaga sumber literasi di saat Belajar di Rumah Masa Pandemi Covid -19 ini pada materi bangun ruang di SD Di dalam pembelajaran $B D R$, selain menggunakan beberapa aplikasi online berupa seesaw class, grub WA terstruktur, chanel You Tube, kahoot dan quiziz. Media pembelajaran matematika Media Beruang Antik menggunakan pembelajaran yang berbasis Science (Sains), Technology (Teknologi), Engineering (teknik), Art (seni) dan Mathematics (Matematika) disingkat STEAM ini dibuat sebagai salah satu bahan literasi numerasi untuk siswa juga digunakan sebagai salah satu solusi mengembangkan kreativitas belajar peserta didik ditengah perkembangan era digital yang semakin pesat, informasi yang semakin mudah didapatkan dari segala sumber serta kecanggihan teknologi. Pada penelitian yang menerapkan dengan pendekatan pembelajaran STEAM yaitu oleh Septiani (2016), hasil dari penelitian menunjukan asesmen kinerja yang diterapkan dalam pendekatan STEM pada materi penyiapan media tanam mampu mengungkapkan keterampilan proses sains peserta didik. Dengan artian dengan melibatkan secara langsung untuk menghasilkan sebuah produk salah satu upaya dalam menggali kreativitas peserta didik. Pada dasarnya STEAM adalah inisiatif menambahkan Seni dan desain kedalam STEM yang sudah menjadi jargon sebelumnya. Maeda (2013) menyatakan "Saya tetap yakin bahwa seniman dan desainer akan menjadi inovator abad ini, dan sebagai pemecahan masalah, keberanian dan pemikiran kritis dan keterampilan mencipta yang saya lihat setiap hari inilah yang dibutuhkan agar negara kita tetap kompetitif. Desainer dan seniman membuat objek, perangkat dan layanan yang lebih menarik, lebih efisien, lebih diinginkan, dan pada akhirnya, bermanfaat bagi manusia.". Salah satu tujuan STEAM adalah siswa dapat mengembangkan ketrampilan berkomunikasi, berfikir kritis, kreatif, mampu berkolaboratif serta dapat mendorong siswa untuk menghasilkan suatu karya. Perkembangan kreativitas guru yang masih minim terhadap model pembelajaran STEAM (Science, Technology, Engineering, Art, and Mathematics) perlu untuk di berikan formula untuk dapat dikembangkan oleh guru hingga ke peserta didik itu sendiri (Amir, 2019).

Pada penggunaan berbasis STEAM dapat dipusatkan dengan aktifitas secara langsung dan nyata. Pendekatan STEAM telah didesain dengan semua tingkatan ataupun gaya mengajar (Yakman \& Lee, 2012). Adapun desain tersebut terdiri dari tiga komponen utama, yaitu mengenali masalah, bertindak secara kreatif dalam perancangan produk, mengembangkan ekspresi dan simpati (Kim \& Chae, 2016). Berdasarkan penelitian Park et al. (2016) bahwasanya penilaian pengajar terhadap pembelajaran berbasis STEAM ini mayoritas dari mereka yang setuju bahwasannya pembelajaran berbasis STEAM memberikan dampak positif, seperti halnya dalam meningkatkan minat peserta didik dalam sains dan matematika.

Media Beruang Antik ini membutuhkan suatu model belajar mengajar yang melatih peserta didik untuk bisa berkolaborasi dengan model Project Based Learning (PjBL) yang terintegrasi dengan STEAM serta mengembangkan budaya literasi numerisasi. 
Khoir, A.K. (2021). Penggunaan Media Beruang Antik Berbasis STEAM pada Materi Bangun Ruang Siswa Sekolah Dasar. Edudikara: Jurnal Pendidikan dan Pembelajaran, 6(3), 176-186.

Hadinugrahaningsih et al. (2017) menyatakan bahwa model pembelajaran PjBL menekankan pada proses belajar mengajar yang kontekstual (nyata) melalui kegiatan-kegiatan yang kompleks dimana peserta didik diajak untuk melaksanakan proyek secara kolaboratif dan pada akhirnya menghasilkan sebuah produk. Sejalan dengan pendapat Wulandari (2021) bahwasannya dalam masa pandemi seperti ini peserta didik cenderung merasakan stres karena beberapa faktor salah satunya dari faktor belajar, namun kondisi seperti ini pendidik yang kreatif dan inovatif dapat mengatasi dengan baik, peserta didik lebih bisa mengatasi saat stres muncul secara tiba-tiba. Dengan demikian harapannya dengan pembelajaran secara daring menjadi stimulus dalam mengembangkan kreatifitas, sedangkan siswa yang diberikan perlakuan berupa nasihat cenderung kesulitan mengatasi stres secara mandiri.

Pendidik yang kreatif dan inovatif sangat berperan penting dalam pengembangan metode belajar yang dapat melibatkan siswa secara langsung. Hal ini memberikan dampak positif kepada peserta didik untuk lebih berpikir kreatif kritis, mampu mengembangkan ketrampilan berkomunikasi, berkolaborasi serta mandiri dalam belajar memecahkan masalah dalam kehidupan nyata dengan menggunakan alat teknologi serta informasi melalui strategi belajar yang kreatif rancangan guru sehinnga mampu menghadapi tantangan di masa depan. Seperti halnya menurut Afriana (2015), bahwasannya dalam pembelajaran berbasis proyek yang pada dasarnya model pembelajaran yang berpusat pada peserta didik dan memberikan pengalaman belajar yang bermakna bagi peserta didik. Pengalaman yang didapat oleh peserta didik mendapatkan sebuah produk yang dihasilkan dalam proses pembelajaran berbasis proyek ini. Pengembangan inovasi berbasis ( $\mathrm{PjBL}$ ) dalam hal literasi numerasi merupakan pengetahuan atau kecakapan yang diperlukan untuk memahami serta mengaplikasikan konsep bilangan pada matematika sehari hari sehingga dapat memecahkan masalah serta menjelaskan informasi yang bersifat kuantitatif yang terdapat di sekeliling siswa. Hal ini juga disampaikan oleh Qasim et al. (2015) Literasi matematika adalah kemampuan peserta didik untuk merumuskan, menerapkan dan menafsirkan matematika dalam berbagai konteks, termasuk kemampuan melakukan penalaran secara matematis dan menggunakan konsep. Pada penerapannya Media Beruang Antik, peserta didik mempraktekkan cara membuat media setelah itu mempresentasikan hasil karya yang telah dikerjakan serta membuat laporan hasil belajar kepada guru. Di sini sangatlah penting peran serta keterlibatan orang tua dalam seluruh aktivitas anak untuk mengarahkan anak berpikir kreatif, bereksplorasi serta memotivasi anak untuk menyelesaikan serta menemukan cara-cara baru dalam penyelesaian berbagai masalah pembelajaran.

\section{METODE}

Pada penelitian ini jenis penelitian pengembangan (research and development) dilakukan dengan modifikasi model Borg \& Gall (Sutama, 2015). Penelitian ini dipusatkan pada pengkajian terhadap program pendesaian suatu produk dengan tujuan dapat menggamabarkan kondisi atau situasi yang sedang terjadi. Model pengembangannya berupa pembuatan media buku modul yang diimplementasikan melalui ( $\mathrm{PjBL}$ ) dalam proses pembelajarannya. Pengembangan media pembelajaran berbasis ( $\mathrm{PjBL}$ ) memuat beberapa ketrampilan dan diimplementasikan pembelajaran. Model pengembangan yang dipakai dalam penelitian ini mengikuti desain (Sutama, 2015) yang menyatakan bahwa penelitian pengembangan merupakan metode penghubung atau pemutus kesenjangan antara penelitian dasar dengan penelitian terapan. Pelaksanaan penelitian pengembangan dilakukan dengan metode deskriptif, evaluatif, dan eksperimental.

Penerapan pembelajaran BDR menggunakan Media Beruang Antik dengan berbasis STEAM ini diterapkan dalam 5 langkah yaitu managemen, perencanaan, persiapan, keterlibatan, dan evaluasi. Setiap tahap pembelajaran ini akan mendorong siswa untuk dapat berpikir kreatif serta aktif dalam menyelesaikan projek yang diberikan, mulai dari pertanyaan pengembangan 
Khoir, A.K. (2021). Penggunaan Media Beruang Antik Berbasis STEAM pada Materi Bangun Ruang Siswa Sekolah Dasar. Edudikara: Jurnal Pendidikan dan Pembelajaran, 6(3), 176-186.

rencana projek, penyiapan jadwal, monitoring pada aktivitas siswa serta kemajuan projek, pengujian dan penilaian hasil, evaluasi pembelajaran.

Pengembangan inovasi pembelajaran matematika yang memberdayakan media Beruang Antik ( Bangun Ruang Warna Bikin Anak Pintar dan Kreatif) berbasis STEAM (Sains, Tecnology, Engineering, Art, Mathematic) pada Materi Bangun Ruang ini merupakan hasil kreativitas guru, harapannya adalah untuk memotivasi belajar peserta didik karena disajikan dalam bentuk sebuah buku ( modul) matematika sederhana yang didalamnya menyajikan beberapa substansi materi bangun ruang berbasis STEAM (Sains, Tecnology, Engineering, Art Mathematic) yang disesuaikan dengan tujuan pembelajaran disetiap tema.
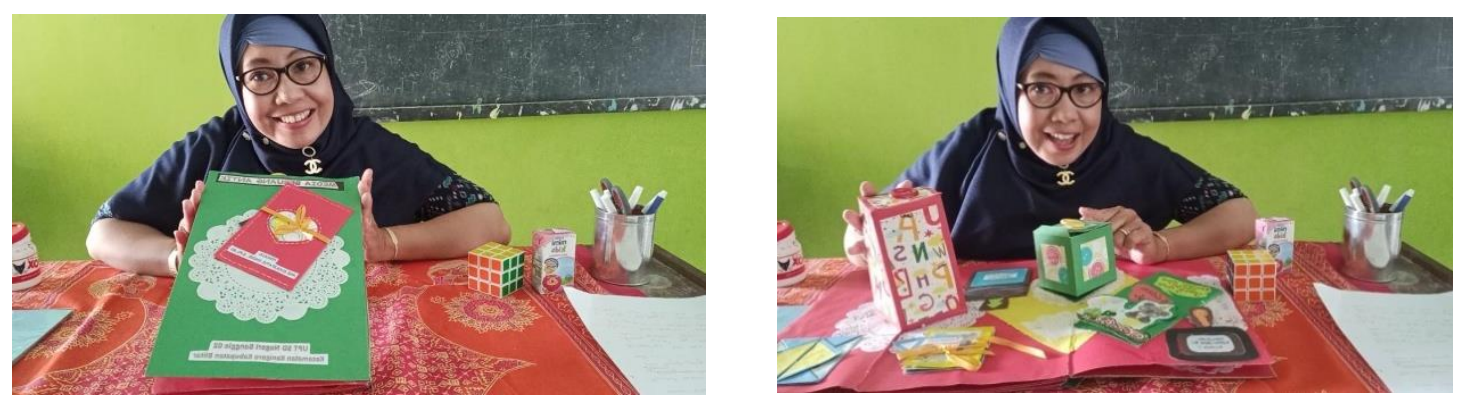

Gambar 1

Inovasi Media Pelajaran Beruang Antik

( Bangun Ruang Warna Bikin Anak Pintar dan Kreatif)

Nama Produk ini dinamakan "Beruang Antik ( Bangun Ruang Warna yang Bikin Anak Pintar dan Kreatif)". Jenis produk ini adalah Media Pembelajaran (Modul) materi Bangun Ruang. Pembuatan produk ini menggunakan bahan bahan diantaranya adalah kertas warna, kertas lipat warna, kertas kado, lem, gunting, penggaris, jangka, dan pensil. Proses pembuatan produk tersebut adalah sebagai berikut, yang pertama menyisipkan dua lembar kertas warna. Kertas pertama dibuat jaring - jaring "Beruang Antik", sedangkan kertas kedua digunakan sebagai media alas untuk merekatkan "Beruang Antik". Selanjutnya memilih bangun ruang yang akan di bentuk. Langkah selanjutnya adalah membuat pola jaring - jaring pada kertas sesuai dengan ukuran yang telah ditentukan, seperti kubus untuk setiap sisinya adalah $7 \mathrm{~cm}$, kemudian untuk balok memiliki ukuran dengan panjang $14 \mathrm{~cm}$ lebar $6 \mathrm{~cm}$ dan tinggi $8 \mathrm{~cm}$, untuk tabung memiliki jari $7 \mathrm{~cm}$ dan tinggi $14 \mathrm{~cm}$. Lalu, pada pola jaring - jaring tersebut di gunting sesuai dengan pola yang telah dibuat, pada pola jaring jaring tersebut bisa juga diberi hiasan menggunakan kertas kado untuk memperindah tampilan "Beruang Antik". Langkah selanjutnya, pada jaring - jaring tersebut digabungkan dan direkatkan menggunakan lem hingga membentuk bangun ruang. Kertas kedua yang digunakan sebagai media untuk merekatkan beruang antik dilipat menjadi dua, sehingga mendapati garis diagonal. Tempelkan alas dari beruang antik tersebut ditengah kertas pertama menggunakan lem. Pastikan saat kertas dibuka, beruang Antik terbentuk menjadi bangun ruang 3 dimensi, dan saat ditutup Beruang Antik dapat terlipat mengikuti kertas kedua sebagai media alas. Buatlah Hiasan berupa bunga atau lainya dengan tekhnik pop up. 
Khoir, A.K. (2021). Penggunaan Media Beruang Antik Berbasis STEAM pada Materi Bangun Ruang Siswa Sekolah Dasar. Edudikara: Jurnal Pendidikan dan Pembelajaran, 6(3), 176-186.
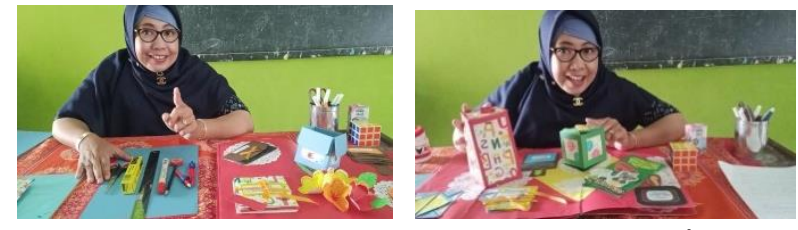

Gambar 2

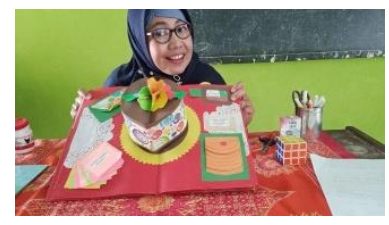

Alat dan Bahan Media Beruang Antik

(Bangun Ruang warna yang bikin anak pintar dan Kreatif)

Tutorial cara pembuatan bisa diakses pada video pembelajaran via chanel YouTube: Media Pembelajaran Beruang Antik Matematika SD, pada tautan berikut ini: https://youtu.be/ccgrX1j Pfo

\section{HASIL}

Ketrampilan berpikir kreatif yang berintegrasi dengan Literasi Numerasi merupakan pusat dari pengembangan kegiatan pembelajaran dengan menggunakan media Beruang Antik berbasis STEAM (Sains, Tecnology, Engineering, Art and Mathematic). Keterampilan berpikir kreatif dengan menggunakan Media Beruang Antik ( Bangun Ruang warna Bikin Anak Pintar dan Kreatif) merupakan salah satu out put yang diharapkan dari kegiatan ini selain itu juga diharapkan siswa dapat mengembangkan budaya literasi numerasi sehingga meningkatkan keterampilan berpikir kritis, berkolaboratif ,trampil berkomunikasi serta mampu meangalisis segala bentuk informasi yang telah didapat, sehingga membentuk siswa berkarakter dan juga siswa mampu menyelesaikan masalah disekitar siswa yang bersifat kuantitatif dan juga siswa dapat mendesain serta membuat sebuah produk dari keterampilan tersebut. Jadi pilihan terbaik untuk memilih model Pembelajaran di masa Pandemi itu harus menggunakan pembelajaran yang berbasis STEAM (Sains, Tecnology, Engineering,Art and Mathematic) dengan demikian membentuk karakter peserta didik yang terampil, mandiri, berpikir kreatif ,kritis,terampil berkomunikasi, bergotong royong, rasa empati terhadap sesama dan pada akhirnya berdampak positif terhadap kegiatan BDR( Blajar dari Rumah) di Masa Pandemi Covid-19 ini. Implementasi $\mathrm{PjBL}$ ( project based Learning) yang berbasis STEAM (Sains, Tecnology, Engineering,Art and Mathematic) menuntut siswa untuk selalu aktif dalam pembelajaran, sehingga disini guru berperan dan bersifat sebagai fasilitator, guru sebagai fasilitator dimaksudkan sebagai penjembatan siswa saat menemukan kesulitan dalam memecahkan masalah yang ditemukan siswa. Seperti halnya diagram dibawah ini: 
Khoir, A.K. (2021). Penggunaan Media Beruang Antik Berbasis STEAM pada Materi Bangun Ruang Siswa Sekolah Dasar. Edudikara: Jurnal Pendidikan dan Pembelajaran, 6(3), 176-186.

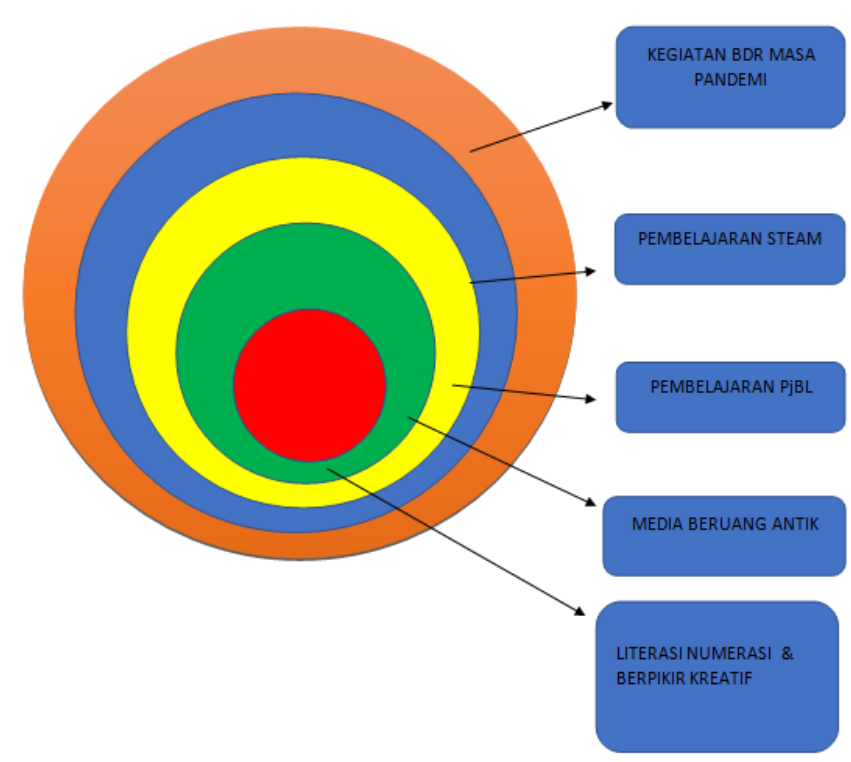

Gambar 5

Hubungan Media Beruang antik, Pembelajaran STEAM , Literasi numerasi dan berpikir kreatif di Masa Pandemi Covid 19

Dari diagram diatas dapat dijelaskan bahwa Pembelajaran yang berpusat pada literasi numerasi yg berintegrasi dengan keterampilan berpikir siswa, model pembelajaran PjBL ( Projec Based Learning) yang berbasis STEAM melalui Media Beruang Antik (Bangun Ruang Bikin Anak Pintar dan Kreatif) di masa Pandemi Covid -19 ini dapat dilaksanakan dalam beberapa tahap pembelajaran. Media Beruang Antik ini sangat efektif di implementasikan pada saat pembelajaran Inti.

Pada kegiatan pembelajaran inti, guru dapat mengintegrasikan budaya literasi numerasi juga dengan mengaitkan pada pemecahan masalah - masalah yang berhubungan dengan pokok bahasan bangun ruang yang bersifat kuantitatif serta ada keterkaitan antara satu dengan yang lainya sehingga tercapai tujuan pembelajaran BDR yang menyenangkan .

Sinkronisasi dan keterpaduan antara kegiatan pembelajaran melalui media bruang antic berbasis STEAM (Sains, Tecnology, Engineering, Art and Mathematic) akan berdampak positif pada Penguatan Pendidikan Karakter (PPK) siswa yang mampu memecahkan masalah - masalah pada kehidupan nyata yang bersifat kuntitatif, serta piawai dalam penggunaan berbagai macam media Pembelajaran yang ada sehingga pada akhirnya dapat meningkatkan hasil belajar siswa sesuai dengan tujuan BDR ( Belajar dari Rumah) yang ingin di capai.

Berikut tahapan aplikasi media Beruang Antik ( Bangun Ruang warna bikin anak pintar dan kreatif) dengan model PjBL berbasis STEAM (Sains, Tecnology, Engineering, Art and Mathematic) dalam kegiatan pembelajaran BDR antara lain : 
Khoir, A.K. (2021). Penggunaan Media Beruang Antik Berbasis STEAM pada Materi Bangun Ruang Siswa Sekolah Dasar. Edudikara: Jurnal Pendidikan dan Pembelajaran, 6(3), 176-186.

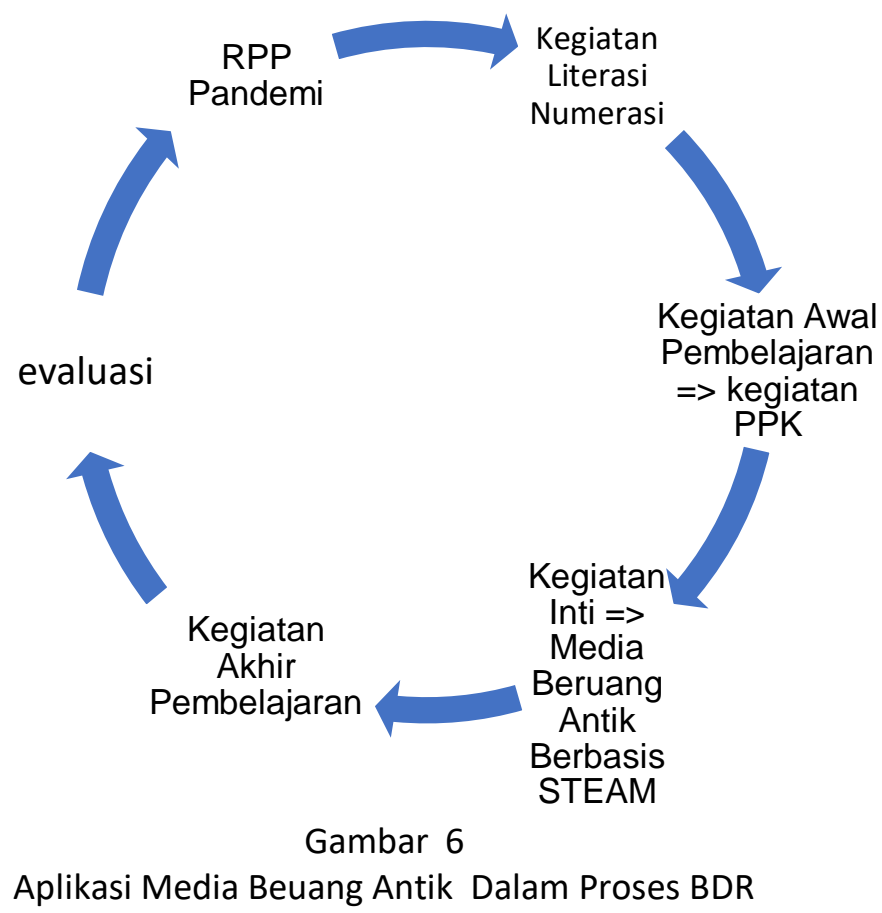

\section{Penerapan Pada Pembelajaran Matematika}

Berdasarkan hasil yang dicapai dalam kegiatan proses pembelajaran melalui media Beruang Antik (Bangun Ruang bikin Anak Pintar dan Kreatif) menggunakan model PjBL yang berbasis STEAM (Sains, Tecnology, Engineering, and Mathematic) diketahui adanya peningkatan hasil belajar siswa. Diketahui hasil belajar siswa Yang diketahui belum adanya perubahan hasil belajar pada kegiatan BDR sebelum mengaplikasikan media Beruang Antik berbasis STEAM (Sains, Tecnology, Engineering,Art and Mathematic) belum mengalami perubahan, terbukti dengan hasil belajar siswa masih mencapai tingkat ketuntasan $77,5 \%$, hal ini dikarenakan oleh kegiatan pembelajaran belum menerapkan media Beruang Antik (Bangun Ruang bikin Anak Pintar dan Kreatif) berbasis STEAM (Sains, Tecnology, Engineering, Mathematic). Perubahan pada hasil belajar siswa meningkat pada hasil kegiatan pembelajaran setelah mengaplikasikan Media Beruang Antik (Bangun Ruang bikin Anak Pintar dan Kreatif) berbasis STEAM (Sains, Tecnology, Engineering, Mathematic), sehingga terdapat perubahan - perubahan baik dari aktivitas peserta didik maupun guru yang pada akhirnya diperoleh hasil belajar siswa mencapai tingkat ketuntasan $87,5 \%$. Keberhasilan ini memberikan deskripsi hasil kuantitatif bahwa media Beruang Antik (Bangun Ruang bikin Anak Pintar dan Kreatif) berbasis STEAM (Sains, Tecnology, Engineering, Mathematic) memberikan efektifitas belajar pada siswa sehingga dapat meningkatkan hasil belajar peserta didik.

Tabel 1

Hasil Belajar Siswa Pada Kegiatan Belajar Sebelum Aplikasi media Beruang Antik (Bangun Ruang bikin Anak Pintar dan Kreatif) berbasis STEAM (Sains, Tecnology, Engineering, Mathematic) 
Khoir, A.K. (2021). Penggunaan Media Beruang Antik Berbasis STEAM pada Materi Bangun Ruang Siswa Sekolah Dasar. Edudikara: Jurnal Pendidikan dan Pembelajaran, 6(3), 176-186.

\begin{tabular}{cccccc}
\hline Nomor & Nilai & Frekuensi & Persentase & Kategori & Keterangan \\
\hline $\mathbf{1}$ & $90-100$ & 5 & $12,5 \%$ & sangat baik & tuntas \\
$\mathbf{2}$ & $80-89$ & 26 & $6,5 \%$ & Baik & tuntas \\
$\mathbf{3}$ & $70-79$ & 5 & $12,5 \%$ & Sedang & tidak tuntas \\
$\mathbf{4}$ & $60-69$ & 4 & $1, \%$ & Kurang & tidak tuntas \\
$\mathbf{5}$ & $50-59$ & 0 & 0 & sangat kurang & tidak tuntas \\
\multicolumn{2}{l}{ Jumlah total } & 40 & & & \\
Jumlah ketuntasan & 31 & $77,5 \%$ & & \\
Jumlah tidak tuntas & 9 & $22,5 \%$ & & \\
\hline
\end{tabular}

Tabel 2

Hasil Belajar Siswa Pada Kegiatan Belajar Sesudah Aplikasi media Beruang Antik (Bangun Ruang bikin Anak Pintar dan Kreatif) berbasis STEAM (Sains, Tecnology, Engineering,

Mathematic)

\begin{tabular}{cccccc}
\hline Nomor & Nilai & Frekuensi & Persentase & Kategori & Keterangan \\
\hline $\mathbf{1}$ & $90-100$ & 15 & $37,5 \%$ & sangat baik & tuntas \\
$\mathbf{2}$ & $80-89$ & 21 & $52,5 \%$ & Baik & tuntas \\
$\mathbf{3}$ & $70-79$ & 3 & $7,5 \%$ & sedang & tidak tuntas \\
$\mathbf{4}$ & $60-69$ & 2 & $5, \%$ & kurang & tidak tuntas \\
$\mathbf{5}$ & $50-59$ & 0 & 0 & sangat kurang & tidak tuntas \\
\multicolumn{2}{l}{ Jumlah total } & 40 & & & \\
Jumlah ketuntasan & 35 & $87,5 \%$ & & \\
Jumlah tidak tuntas & 5 & $12,5 \%$ & & \\
\hline
\end{tabular}

Grafik 1

Hasil Aplikasi Penggunaan Media Beruang Antik (Bangun Ruang warna Bikin Anak Pintar dan Kreaatif) berbasis STEAM (Sains, Tecnology, Engineering, Art and Mathematic)

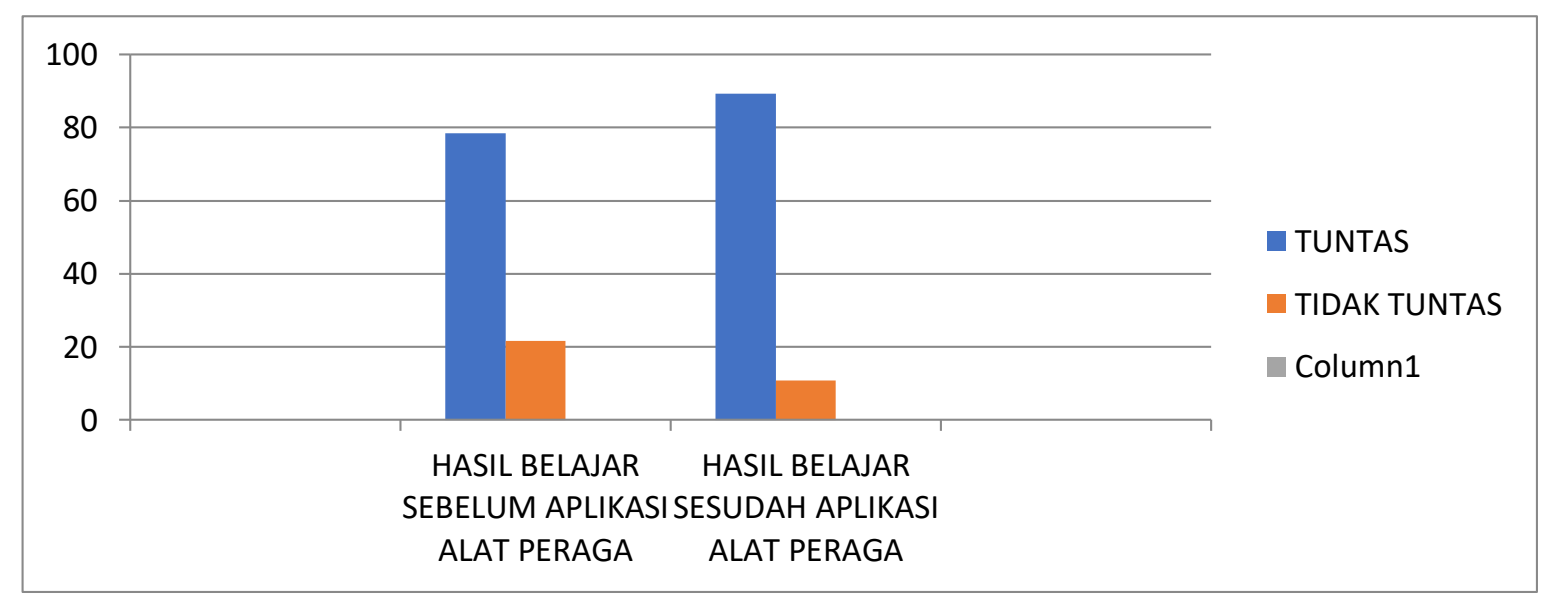

\section{SIMPULAN DAN SARAN}

Karakteristik produk Penggunaan Media Beruang Antik (Bangun Ruang bikin Anak Pintar dan Kreatif) berbasis STEAM (Sains, Tecnology, Engineering, Mathematic) pada Materi Bangun Ruang Kelas VI SD dari bukti-bukti yang ada siswa dapat meningkatkan keterampilan berpikir kritis, berkolaboratif ,trampil berkomunikasi serta mampu meangalisis segala bentuk informasi yang telah didapat, sehingga membentuk siswa berkarakter dan siswa juga mampu 
Khoir, A.K. (2021). Penggunaan Media Beruang Antik Berbasis STEAM pada Materi Bangun Ruang Siswa Sekolah Dasar. Edudikara: Jurnal Pendidikan dan Pembelajaran, 6(3), 176-186.

menyelesaikan masalah dan membuat medesain sebuah produk hasil karya siswa sendiri . Penggunaan Penggunaan Media Beruang Antik (Bangun Ruang bikin Anak Pintar dan Kreatif) berbasis STEAM (Sains, Tecnology, Engineering, Mathematic) pada Materi Bangun Ruang Kelas VI SD Untuk Meningkatkan Ketrampilan berpfikir kreatif siswa juga memberikan dampak positif yang penting atau signifikan pada aktivitas siswa, hal ini ditunjukkan dengan hasil belajar siswa yang meningkat.

Dengan diberikan eksperimen seperti ini Sekolah diharapkan senantiasa memfasilitasi para guru-guru dalam mengembangkan inovasi pembelajaran untuk menunjang semua kegiatan pembelajaran BDR ataupun dalam Kelas. Sekolah juga memberikan dukungan dan pelatihan terhadap para guru agar lebih produktif dalam menghasilkan karya inovasi pembelajaran. Selain itu Guru lebih aktif dalam mengikuti perkembangan informasi tekhnologi yang semakin pesat berkembang di masa ini sehingga dapat mengikuti perkembangan kurikulum pendidikan yang senantiasa bersifat dinamis. Guru harus selalu pro aktif terhadap perubahan perubahan yang terjadi dalam paradigma pendidikan sehingga mampu mengikuti tuntutan pembelajaran abad ke-21 menuju abad ke- 45 yang menjadi salah satu pengembangan dari kurikulum nasional yaitu kurikulum 2013.

\section{REFERENSI}

Afriana, J. (2015). Project based learning (PjBL). Bandung: Sekolah Pascasarjana UPI.

Amir, R. H. (2019). Efektivitas Model Pembelajaran Steam (Science, Technology, Engineering, Art, And Mathematics) Dalam Pembelajaran Ipa Konsep Sumber Energi Pada Siswa Kelas Iv Sd Pertiwi Makassar. Universitas Muhammadiyah Makassar.

Anugrahana, A. (2020). Hambatan, solusi dan harapan: pembelajaran daring selama masa pandemi covid19 oleh guru sekolah dasar. Scholaria: Jurnal Pendidikan Dan Kebudayaan, 10(3), 282-289.

Firman, F., \& Rahayu, S. (2020). Pembelajaran online di tengah pandemi covid-19. Indonesian Journal of Educational Science (IJES), 2(2), 81-89.

Hadinugrahaningsih, T., Rahmawati, Y., \& Ridwan, A. (2017). Developing 21st century skills in chemistry classrooms: Opportunities and challenges of STEAM integration. AIP Conference Proceedings, 1868(1), 30008.

Ismail, S., Sodikin, O., \& Hasanah, A. (2020). Evaluasi Implementasi Pendidikan Karakter di Sekolah. Jurnal Al-Amar (Ekonomi Syariah, Perbankan Syariah, Agama Islam, Manajemen Dan Pendidikan), 1(3), 20-27.

Surat Edaran Nomor 15 Tahun 2020 tentang Pedoman penyelenggaraan belajar dari rumah dalam masa darurat penyebaran corona virus disease (Covid-19), (2020).

Kemendikbud. (2020). Pedoman Penyelenggaraan Belajar dari Rumah dalam Masa Darurat Penyebaran Corona Virus Disease (Covid-19). Kemdikbud.

Khusniyah, N. L., \& Hakim, L. (2019). Efektivitas Pembelajaran Berbasis Daring: Sebuah Bukti Pada Pembelajaran Bahasa Inggris. Jurnal Tatsqif, 17(1), 19-33.

Kim, H., \& Chae, D.-H. (2016). The development and application of a STEAM program based on traditional Korean culture. Eurasia Journal of Mathematics, Science and Technology Education, 12(7), 19251936.

Maeda, J. (2013). Stem+ art= steam. The STEAM Journal, 1(1), 34.

Mahaly, S. (2021). Persepsi Mahasiswa Terhadap Pelaksanaan Pembelajaran Daring Selama Masa Pandemi. Edudikara: Jurnal Pendidikan Dan Pembelajaran, 6(2), 109-116.

Park, H., Byun, S., Sim, J., Han, H.-S., \& Baek, Y. S. (2016). Teachers' perceptions and practices of STEAM education in South Korea. Eurasia Journal of Mathematics, Science and Technology Education, 12(7), 1739-1753.

Primasari, R., Zulfiani, Z., \& Herlanti, Y. (2014). Penggunaan media pembelajaran di madrasah aliah negeri se-Jakarta Selatan. Edusains, 6(1), 67-72.

Qasim, Kadir, \& Awaluddin. (2015). Deskripsi Kemampuan Literasi Matematika Siswa SMP Negeri Di Kabupaten Buton Utara. Jurnal Penelitian Pendidikan Matematika, 3(3).

Septiani, A. (2016). Penerapan Asesmen Kinerja dalam Pendekatan Stem (Sains Teknologi Engineering 
Khoir, A.K. (2021). Penggunaan Media Beruang Antik Berbasis STEAM pada Materi Bangun Ruang Siswa Sekolah Dasar. Edudikara: Jurnal Pendidikan dan Pembelajaran, 6(3), 176-186.

Matematika) untuk Mengungkap Keterampilan Proses Sains. Isu-Isu Kontemporer Sains, Lingkungan, Dan Inovasi Pembelajarannya, 654-659.

Siahaan, M. (2020). Dampak pandemi Covid-19 terhadap dunia pendidikan. Dampak Pandemi Covid-19 Terhadap Dunia Pendidikan, 20(2).

Sudarmoyo, S. (2020). Podcast sebagai Alternatif Media Pembelajaran Jarak Jauh. Edudikara: Jurnal Pendidikan Dan Pembelajaran, 5(2), 65-73.

Sutama. (2015). Metode Penelitian Pendidikan Kuantitatif, Kualitatif, PTK, R\&D. Fairuz Media.

Wulandari, S. W. R. (2021). Mengatasi Stres di Masa Pandemi Covid-19 melalui Hipnoterapi. Edudikara: Jurnal Pendidikan Dan Pembelajaran, 6(2).

Yakman, G., \& Lee, H. (2012). Exploring the Exemplary STEAM Education in the U.S. as a Practical Educational Framework for Korea. Journal of The Korean Association For Science Education, 32(6), 1072-1086. https://doi.org/10.14697/jkase.2012.32.6.1072 